\title{
ICOM \\ Research catches up with the unstoppable reality of science communication through online video
}

Reviewed Book

Reviewed by

Abstract

Keywords

DOI
LEÓN, B. AND BOURK, M. EDS. (2018).

COMMUNICATING SCIENCE AND TECHNOLOGY THROUGH ONLINE VIDEO.

NEW YORK, U.S.A.: TAYLOR AND FRANCIS (ROUTLEDGE)

\section{Erik Stengler and Hannah Sherman}

A timely arrival in the academic literature on science communication through online video, this book reports on the results of a major international project that has explored in depth this emerging field of research.

Popularization of science and technology; Public perception of science and technology; Science and media

https://doi.org/10.22323/2.18020701

Submitted: 20th December 2018

Accepted: 17th January 2019

Published: 18th February 2019

While online video has become synonymous with web-based searches for the younger generations and the communication of science and technology has jumped on the bandwagon of this trend, too, relatively little research has been undertaken on this phenomenon. Over the last few years a small group of scholars from different institutions have independently begun to explore this field and to discuss their findings at international conferences, as reported previously in Allgaier and Geipel [2016] and in this journal in Stengler [2016]. Some articles have become essential references, such as Welbourne and Grant [2016] and Muñoz Morcillo, Czurda and Robertson-von Trotha [2016]. While there was an e-book published in German on the topic [Körkel and Hoppenhaus, 2016], and an extensive review will also be included in the Second International Handbook of Internet Research [Allgaier, 2020, to appear], the book Communicating Science and Technology Through Online Video edited by Bienvenido León and Michael Bourk is a timely arrival in the academic literature and shows that a critical mass of research in the field is being reached.

"Communicating Science and Technology through Online Video: Researching a New Media Phenomenon" introduces the reader to an international research project titled "Videonline". A summary of the aims and objectives of the project is 
presented by the team of researchers in the format of an online video under the link: https://www.youtube.com/watch?v=paSUvXZP_Iw. León is a principal researcher on the project, as well as an Associate Professor focusing on Science Journalism and Television Production from the University of Navarra in Spain, and Bourk is also a principal researcher on this project and works as an Associate Professor of Mass Communication with the Gulf University for Science and Technology in Kuwait.

The main theme of the "Videonline" project is the process of communicating science to the public through online videos. The book is structured in 10 chapters. After an introduction in chapter 1 , each of the following 8 chapters presents a study, its results and conclusions. The studies analyze different aspects and elements that are crucial to anyone intending to enter the world of online science video communication, and to understand the ways in which the viewers utilize the information. Many of these studies highlight how online science videos are a completely different from and not just a development of other well-known traditional formats like film and TV, as for example in terms of narratives, control of content and expertise, or the completely new challenges posed by the social nature of these new media. Chapter 10 brings all the aspects together into an overall conclusion and the discussion of the many areas of research that this project has begun to address.

The editors introduce the project in chapter 1 by detailing the relevance of communicating science online in the 21st century once online communication has sky-rocketed over the previous decades and the internet has become the place for conversations to occur. Chapter 2 proposes a classification of online video formats that constitutes the research group's core development for the study of all areas addressed in the following chapters, and that has been reported as applied to Climate Change by the authors in De Lara, García-Avilés and Revuelta [2017]. Chapter 3 addresses the production of online videos including the different players (producers and scientists), formats and objectives.

Chapter 4 explores online videos about three scientific topics that are currently part of societal controversies: climate change, nanotechnology, and vaccines. The topics are introduced to investigate how intellectual rigor and diverse challenges are faced in online video science communication, when political, social, and economic pressures play a role in the way science is communicated to the public.

Further challenges to online video science communication are covered in successive chapters: the transition from traditional TV documentary formats to the digital environment (chapter 5) - a topic further explored by one of the researchers in Erviti and Stengler [2016]; the concerns about rigor caused by the inherent lack of control over user-generated content (chapter 6); and the missed opportunities, both by Universities to position themselves as prominent reliable primary sources of information (chapter 7) and by communicators of Climate Change to learn from the past and re-frame the topic in a more positive way for the younger generations that constitute the audience of online videos (chapter 9).

Chapter 8 revisits the transition from TV to online video with a focus on the balance between information and entertainment — and their middle ground known as infotainment. 
The conclusions of all chapters point out how they have just opened up the topic to a whole range of new questions to be addressed by further research. Chapter 10 summarizes these new questions and sets the scene for a promising future of research in this field. This book is therefore an essential tool not only for those involved in the production of online science videos, who will find in it valuable pointers to inform their work with evidence-based insights, but for anyone entering this emerging and underexplored field as a researcher.

\section{References}

Allgaier, J. (2020, to appear). 'Science and medicine on YouTube'. In: Second International Handbook of Internet Research. Ed. by J. Hunsinger, L. Klastrup and M. M. Allen. New York, U.S.A.: Springer.

Allgaier, J. and Geipel, A. (2016). The role of webvideos in science and research communication. Report on a special science communication session at the 15th Annual STS Conference in Graz, Austria, May 9-10, 2016. URL: https: //sagepu s.blogspot. com/2016/09/the-role-of-webvideos-in-science-and.html (visited on 20th December 2018).

De Lara, A., García-Avilés, J. A. and Revuelta, G. (2017). 'Online video on climate change: a comparison between television and web formats'. JCOM 16 (01), A04. https://doi.org/10.22323/2.16010204.

Erviti, M. C. and Stengler, E. (2016). ‘Online science videos: an exploratory study with major professional content providers in the United Kingdom'. JCOM 15 (06), A06. https://doi .org/10.22323/2.15060206.

Körkel, T. and Hoppenhaus, K., eds. (2016). Web, Video, Wissenschaft. Heidelberg, Germany: Spektrum der Wissenschaft. URL: https ://www . spektrum . de/fm/976 /Web\%20Video\%20Wissenschaft\%20Version\%201_02.pdf (visited on 20th December 2018).

Muñoz Morcillo, J., Czurda, K. and Robertson-von Trotha, C. Y. (2016). 'Typologies of the popular science web video'. JCOM 15 (04), A02. https://doi.org/10.22323/2.15040202.

Stengler, E. (2016). '15th Annual STS Conference Graz 2016'. JCOM 15 (04), R02. https://doi.org/10.22323/2.15040602.

Welbourne, D. J. and Grant, W. J. (2016). 'Science communication on YouTube: factors that affect channel and video popularity'. Public Understanding of Science 25 (6), pp. 706-718. https://doi .org/10.1177/0963662515572068.

\section{Authors}

Erik Stengler is Assistant Professor in Science Museum Studies. In addition to Science Museums and Planetariums, his special interests include also Science in Film and, more broadly, how to succeed in communicating science to those not particularly interested in it. He has extensive experience in Communicating Science informally in Science Centres, through Outreach Projects and in the Media. He has been project manager of various initiatives that range from a Science Van to Courses on Science in the Movies, including a TV children's show; theatre plays; science programmes for senior citizens, in prisons or in leisure environments; and educational partnerships with Science Historians. Erik has been involved in the training of museum explainers and in various teacher training programmes. E-mail: ArisErik.Stengler@oneonta.edu. 
Hannah Sherman is a second-year science track student at SUNY Oneonta's Cooperstown Graduate Program of Museum Studies. She has a degree in Biology and her interests include BioBlitzes and citizen science.

How to cite

Stengler, E. and Sherman, H. (2019). 'Research catches up with the unstoppable reality of science communication through online video'. JCOM 18 (02), R01. https://doi.org/10.22323/2.18020701. 